\title{
THE RESPONSIBILITY OF TEACHERS FOR DEVIATIONS FROM PROFESSIONAL ETHICS IN THE REGULATION OF LAW NO. 1/2011. PRACTICAL ASPECTS
}

\author{
Laura MANEA ${ }^{1}$
}

\begin{abstract}
In the current regulation of the Law of national education no. $1 / 2011$ is granted a special section for deviations from the university ethics, a section distinct from the section of disciplinary deviations.

The common element that creates also confusion in practice between the two types of responsibilities is the similar terminology used by the legislator "disciplinary sanctions" in both section, although analyzing the administrative research procedures established in the two sections, we find a different legal regime both in terms of the activity of the two commissions of research, as well as of the documents issued following the procedures.
\end{abstract}

Key words: university ethics commission, disciplinary sanction, decision, report.

\section{Introduction. University Ethics}

The principles and the rules of moral conduct have always been present in the university environment, but most of the time under the form of some unwritten rules regarding the relations between a university professor and a student, of certain academic customs and professional best practices regarding the scientific and didactic research activity which vary from one university to another. Some mistake the university ethics with the Christian moral, present outside the university, in society and in everyday life.

The academic morality (rules of moral conduct among the members of the academic community) and that of research are not parts of "common morality", but are forms of institutional and professional teaching ethics, thus being limited to certain actions specific to teaching and research.

Also functioning as an institution, the university as a legal entity is an organization, in which sense we can also talk in the case of this institution about a general and collective level of morality which is beyond the morality of each member of that institution. This is because universities are, in turn, an environment in which a combination of organizational practices that can be subjected to moral evaluation develops, as Kaptein and Wempe1 argue.

\footnotetext{
${ }^{1}$ Transilvania University of Braşov, manea@unitbv.ro, PhD student at the Institute of Legal Research “Acad. Andrei Rădulescu"
} 
A university is moral if its current practices (the context or the university environment) stimulate its members to adopt a moral conduct (Socaciu E., Vică C., et al., 2018, p.68).

Speaking of a system of rewards and sanctions for the organizational behavior, in the case of universities we also identify procedures that punish the violations of moral rules and reward the moral behaviour of its members (sense in which we mention the introduction in the evaluation procedures of indicators on moral conduct in relation to the activity of professors - art.303 Law no.1 / 2011, or by the immediate and firm sanctioning of copying or falsification of data in scientific research contracts - art. 2 and art.3 Law no.206 / 2004).

Thus, the members of the academic community are encouraged to repeat moral behaviours, receiving a reward in return for their behaviour, and are discouraged from breaking the rules, avoiding the imposition of a sanction applied through a decision of the rector.

Equally, sanctions or rewards must be proportional to the seriousness of the infringements and to the merit of complying with certain ethical rules.

The universities in Romania (and around the world) have adopted Codes of Ethics which are committed to respecting a series of general ethical values and principles, from which specific moral rules derive, with the role of guiding ethical decisions and providing a model of moral behaviour. Moral values are cultural standards valid for all the members of the organization, which guide our moral behaviour (Socaciu E., Vică C., et al., 2018, p.88).

In reality, the Codes of University Ethics do not function as a behavioural guide, but rather represent a moral landmark, incorporating in their content the ethical principles based on social and moral values.

A code of ethics based on moral values is a code based on a declaration of values, such as, for example, the codes of the Romanian universities. The ethical principles are not rules of conduct, but major criteria that establish and justify the rules of conduct that must be observed by the members of the academic community (Socaciu E., Vică C., et al., 2018, p.88).

Given that the most important moral rules of a society are often taken over and turned into laws, thus attaching to them a series of legal sanctions in case of noncompliance, we also find among the moral rules related to the academic community several examples of such enactments ( Law no.1 / 2011, Law no.206 / 2004).

\section{Regulations specific to university ethics}

Through a series of normative acts, starting with 2002, various aspects of behavioural ethics and academic integrity regarding scientific research have been regulated in Romania, but only through the Education Law no. 1/2011 could the concrete legal framework of activity of the Ethics Commission be created, and the Code of University Ethics associated with the University Charter by including it as a component part of the charter.

Analyzing the normative and administrative acts representative on academic ethics, we present below a selection of them in chronological order, together with the main provisions considered to be relevant for ethics and academic integrity, such as regulations on plagiarism and data falsification, the university code of ethics, the establishment of commissions and councils of university ethics, ensuring the quality of the university education or the introduction of the courses of ethics and academic integrity in the university curriculum: 
Government Ordinance no. 57/2002 on scientific research and technological development - provides the framework for organizing research and development activities, including scientific research (which includes fundamental research and applied research), experimental development and innovation based on scientific research and experimental development.

Law no. 206/2004 on good conduct in scientific research, technological development and innovation - defines deviations such as plagiarism and self-plagiarism, making up and falsifying data; provides for the establishment of the National Council for Ethics of Scientific Research, Technological Development and Innovation (CNECSDTI) as an advisory body, without legal personality, of the Ministry of Research and Innovation (MCl), which carries out specific activities such as: monitors the application and compliance with the legal provisions regarding research ethics and deontology by the units and institutions of the national research-development and innovation system (RDI), as well as by the research-development staff; elaborates reports with analyses, opinions and recommendations in connection with the ethical issues raised by the evolution of science and knowledge and with the professional ethics and deontology in the researchdevelopment activity; proposes amendments to the Code of Ethics and Professional Deontology for Research and Development Staff; develops and makes proposals on codes of ethics in scientific fields, regarding the international best practices.

$>$ Order of the Ministry of Education and Research no. 4492/2005 on the promotion of professional ethics in universities - introduces the obligation of the accredited higher education institutions or authorized to operate provisionally to adopt their own Code of University Ethics, which should include the explicit formulation of ideals, principles and moral norms that the members of the academic community agree to respect and to follow in their professional activity.

The Code of University Ethics is a mandatory document, which completes the University Charter and sets out the standards of professional ethics that a university community aims to follow, as well as the penalties that may apply in the event of a breach. The same order introduces the obligation of higher education institutions to establish a University Ethics Commission, subordinated to the university senate, with responsibilities for drafting the Code of University Ethics, analysis and resolution of complaints and notifications regarding deviations from university ethics, etc.

In addition, the order provides for the establishment of the University Ethics Council at the level of the Ministry of Education and Research, with responsibilities such as: providing advice and monitoring of the application of university ethics codes in higher education institutions accredited and authorized to operate provisionally; dissemination of good practices for the elaboration and application of university codes of ethics; ex officio notification in connection with cases of violation of university ethics in the situation where higher education institutions do not observe on their own initiative.

$>$ Government Emergency Ordinance no. 75/2005 on ensuring the quality of education provides for the establishment of the Romanian Agency for Quality Assurance in Higher Education (ARACIS), an agency that formulates and periodically reviews the national reference standards and performance indicators for assessing and ensuring quality in higher education (previously provided by the National Council for Academic Evaluation and Accreditation). 
National Education Law no. 1/2011 - provides for the establishment of the University Ethics and Management Council (CEMU) as an advisory body of the Ministry of National Education, without legal personality, whose mission is to develop a culture of ethics and integrity in the Romanian universities.

The role of CEMU is to determine and support universities to develop and implement ethics and university integrity policies. CEMU audits the ethics and academic integrity commissions of universities. Chapter III decides on university ethics disputes based on a Reference Code of university ethics and deontology (which it elaborates).

Order of the Minister of National Education no. 3131 / 2018 on the inclusion in the curricula, for all university study programs organized in higher education institutions in the national education system, of courses of ethics and academic integrity provides the obligation of masters and doctoral students to participate in courses of ethics and academic integrity with a duration of at least 14 hours, starting with the academic year 2018-2019; courses are optional for the BA/BSc level.

\section{The role and nature of the University Ethics Commission}

The University Ethics Commission represents a structure of the university, with independent functioning, it operates based on the provisions of the National Education Law no. 1/2011, with subsequent amendments and completions, and of Law no. $206 / 2004$ on good conduct in scientific research, technological development and innovation, with subsequent amendments and completions, this being both a legal definition of the Ethics Commission (art. 306 Law no. 1/2011) and a regulatory definition found in most of the University Ethics Codes of higher education institutions.

Starting from its role, the attributions of the Ethics Commission in general are the following: a) it contributes to the elaboration and revision of the Code of University Ethics and Deontology proposed to the University Senate for adoption and inclusion in the University Charter, according to the Education Law no.1 / 2011 ; b) it pursues the observance of the Code of Ethics and University Deontology; c) analyses and solves the deviations from the university ethics, based on the notifications, according to the Code of Ethics and University Deontology; d) it appoints analysis commissions for the examination of the notifications regarding the deviations from the Code of Ethics or from the good conduct in the research-development activity brought to its attention following the notifications; e) it organizes investigations and researches in order to collect data regarding the cases that are the object of the notifications, in plenary or through analysis commissions, as the case may be; f) it keeps confidential the identity of the author of the notification, in accordance with the law; g) it approves the reports of the analysis commissions and recommends sanctions, if applicable, based on the Code of University Ethics and Deontology and the legislation in force; $h$ ) decides on the nature of the facts that are the object of the notifications and establishes the sanction applicable for the violation of the ethical norms.

Considering the legal provisions of art.308 in connection to art.320 and art.322 of the Law on National Education no.1 / 2011 on engaging the responsibility of the educational institution regarding the decisions of the University Ethics Commission, respectively the fact that the rector is obliged to put into execution the decision of the University Ethics Commission, without the interposition of other bodies of the University, results from the 
interpretation of the legal texts that the legislator's vision was to place this Commission, through its moral role, over the deliberative and executive bodies of the University. Thus, being a decision-making body that establishes, based on the research conducted, the existence of the deviation from ethics and the application of the corresponding sanction (art. 320 of Law no. 1/2011 expressly provides that in case of deviations from the provisions of the Code of Ethics and Professional Deontology, the university ethics commission establishes, according to the Code of professional ethics and deontology, one or more of the sanctions provided in article 318 (not applicable to professors) or 319(not applicable to students)), the enforcement of the sanction is done by the rector's decision or that of the dean, according to art. 322 of Law no. 1/2011. From the perspective of this text of law (art.320 Law no.1 / 2011) we appreciate that we are in the presence of a complex administrative act, so we cannot separately address the decision of the University Ethics Commission and the decision of the rector to sanction for deviating from the university ethics.

Another consequence resulting from the position of the University Ethics Commission is the nature of the administrative act of the Commission's decision, imprinted by the role of the commission and the procedures followed, even if the analysis of the commission includes certain aspects of the employment relationship among the academics.

The legal nature of administrative act of the decision pertaining to the University Ethics Commission also results from the fact that in cases where students are investigated for deviations from university ethics, sanctions are applied (according to art. 319-320 of Law no. $1 / 2011$ ) also by the decision of the Ethics Commission and the decision of the dean or rector, in the case of students this could not be a disciplinary violation (there is no employment relationship between student and university), but a deviation from the university ethics found and sanctioned on an administrative procedure. In this respect, it is also conclusive that the sanctioning decision and the decision of the Ethics Commission are subject to the control of legality before the administrative contentious court. From this perspective, we cannot agree with the idea that a body, the ethics commission, issues an administrative act in the case of students, and in the case of professors, an act limited to the legislation and procedure of labour disputes is issued.

\section{Conclusions}

Considering the practice of the Romanian courts regarding the contestation and verification of the legality of the sanctioning decisions for deviations from the university ethics, in the sense that starting from the existing labour relationship between the investigated professor and the university, the sanctioning decisions and the decision of the University Ethics Commission are assimilated to the disciplinary investigation procedure and, implicitly, to the regulations of the labour legislation, we consider that in relation to the texts of Law no.1 / 2011 (art.306 - art. 310 and art.318-art.326) the intervention of the legislator becomes mandatory in the sense of clearly explaining the administrative act regime of the decision of the University Ethics Commission.

We consider the intervention of the legislator for clarification necessary and useful because the University Ethics Commission is a body placed above the decision-making bodies of universities (the decision of the Ethics Commission is not subject to the approval of the university senate or the board) and has a role of research and 
sanctioning the professor's conduct in relation to professional ethics (behaviour associated not only with the teaching act, but also with the scientific research activities), respectively with the investigation and sanctioning of students, regardless of the study cycle, from the perspective of respecting ethics in learning activities and displaying the knowledge acquired during the studies, but also of an adequate conduct to the university environment and respecting the values of the academic community.

The fact that in the text of art.318 of Law no.1 / 2011 listing the sanctions that can be applied by the University Ethics Commission, the disciplinary termination of the employment contracts also mentioned is not a sufficient element to frame the research procedures of the commission of university ethics in the field of labour law regulations, as the employment relationship of the professors with the higher education institution involves both teaching and research, both areas comprising regulations on the principles and values of behavioral ethics, even more, in the case of research activities there are distinct regulations from which the character of administrative act of the ethics commission results.

\section{References}

Socaciu E., Vică, C., Mihailov, E., Gibea, T, Mureșan V., Constantinescu, M. (2018). Etică și Integritate Academică [Ethics and Academic Integrity]. Bucharest: Editura Universității din București.

*** Ordonanţa Guvernului nr. 57/2002 privind cercetarea ştiinţifică şi dezvoltarea tehnologică [Government Ordinance no. 57/2002 on scientific research and technological development], publicată în Monitorul Oficial nr.643/30.08.2002

*** Legea nr. 206/2004 privind buna conduită în cercetarea ştiinţifică, dezvoltarea tehnologică şi inovare [Law no. 206/2004 on good conduct in scientific research, technological development and innovation], publicată în Monitorul Oficial nr.505/04.06.2004

*** Ordinul Ministerului Educatiei și Cercetării nr. 4492/2005 privind promovarea eticii profesionale în universități [Order of the Ministry of Education and Research no. $4492 / 2005$ on the promotion of professional ethics in universities], publicat în Monitorul Oficial nr.505/11.07.2005

*** Ordonanța de Urgență a Guvernului nr. 75/2005 privind asigurarea calităţii educaţiei [Government Emergency Ordinance no. 75/2005 on ensuring the quality of education], publicată în Monitorul Oficial nr.642/20.07.2005

*** Legea Educației Naționale nr. 1/2011 [National Education Law no. 1/2011], publicată în Monitorul Oficial nr.112/09.02.2011

*** Ordinul Ministrului Educatiei Nationale nr. 3.131/2018 privind includerea în planurile de învățământ, pentru toate programele de studii universitare organizate în instituţiile de învăţământ superior din sistemul naţional de învăţământ, a cursurilor de etică şi integritate academic [Order of the Minister of National Education no. 3,131 / 2018 regarding the inclusion in the curricula, for all university study programs organized in the higher education institutions from the national education system, of the courses of ethics and academic integrity], publicat în Monitorul Oficial nr.140/14.02.2018 